\title{
The Level of Social Capital And Its Effect on The Participation of Farmers on Goat Livestock Business Development In Jeneponto Regency South Sulawesi Province-Indonesia
}

\section{Tanri Giling Rasyid., ${ }^{2}$ ST.Rohani, ${ }^{3}$ Muhammad Aminawar, ${ }^{4}$ Muhammad Darwis}

1,2,3 Faculty of Animal Science Hasanuddin University.

${ }^{4 C}$ enter for Research and Development of the Dynamics of Society, Culture and Humanities Institute for Research and Community Service (LP2M) Hasanuddin University Street Perintis Kemerdekaan KM. 10 Kampus Unhas Tamalanrea, Makassar, South Sulawesi Province-Indonesia.

Correspondence Author: Tanri Giling Rasyid., Faculty of Animal Science Hasanuddin University. E-mail: tanri.giling@gmail.com

Received date: 10 January 2018, Accepted date: 28 February 2018, Online date: 10 March 2018

Copyright: (c) 2018 Tanri Giling Rasyid et al. This is an open-access article distributed under the terms of the Creative Commons Attribution License, which permits unrestricted use, distribution, and reproduction in any medium, provided the original author and source are credited.

\begin{abstract}
the criteria for livestock business development determined by Jeneponto Regency Head are able to contribute significantly or potentially high to goat production. In goat farming business, goat farmers are usually joined in groups. One of the factors that influence the development of a group is the social capital and the level of participation within the group itself. This study aims to (1) describe the level of social capital of goat breeders; (2) to describe the participation of goat breeders; and (3) analyze the influence of social capital with goat breeder participation level in Jeneponto Regency. The method used in this research is descriptive research. From 11 districts in Jeneponto Regency, 3 districts have the largest number of goats, Tamalatea district (32,516 tails), Bontoramba district (19,336 tails), Kelara district (15,873 tails) (BPS Jeneponto, 2016). From each district, 25 farmers were chosen as the respondent or the sample farmer so that the totals were elected 75 goat farmers. The sampling technique was done randomly simple. The research data collected cover the characteristics of social capital of farmers (trust, network, and social norm). The results showed that (1) the level of social capital in the goat breeder group in Jeneponto Regency is still low from all aspects of social capital ie manual trust, reciprocity, and networking; (2) goat breeder participation rate in Jeneponto Regency is in high category; and (3) social capital significantly affect the participation of goat farmers in Jeneponto Regency.
\end{abstract}

Key words: Social capital of farmers, participation of farmer groups, goats.

\section{INTRODUCTION}

The criteria for livestock business development determined by Jeneponto Regency Head are able to contribute significantly or potentially high to goat production in Jeneponto Regency, facilitated by Regional Income and Expenditure Budgets of district and supported by state budget, and supported by Regional Income and Expenditure Budgets of South Sulawesi Province. The decrease in goat livestock population after field identification was indicated that the model of goat breeding business development has not been run as expected or there is still an element that is stipulated in the general guidance of the implementation of the area activity based on the Regulation of the Minister of Agriculture Number. 50 / permentan / OT.140 / 8/2012 has not been applied by the perpetrators of the activity so as to give an indication that goat livestock business has not contributed to increase production, productivity and income and welfare of goat farmers. Thus for the purpose of improving the development of goat farming business needs to find solutions through research strengthening social capital institutions and its impact on the development of goat-based socio-economic economic through a characteristic review approach that includes the management of natural resource utilization and human resources and supporting potentials that support the development of livestock business goats, so it can be recommended model of sustainable goat livestock business development that is feasible cultivated. The same opinion [1] Livestock as one of the agricultural sub-sector was an integral part of the success of the sector in Indonesia. The vision of agricultural development was a cultured livestock industry by industrial base.

Many things to consider encouraging the development of goat breeding business, one of which is to consider the characteristics and geographical conditions, ecology, and soil fertility. The research of development model of goat farming business base on productive economy was designed into application research with research design "Pretest and posttest control group design" doing in two group of goat farmers [2]. In addition, the most important thing to note is the quality of human resources, in this case the goat breeders. In goat farming business, goat farmers are usually joined in groups. The goal is that goat farmers who are members of farmer groups-cattle are able to cooperate with each other, and become a dynamic and growing group. Patterns of partnership or cooperation have already existed in the community of farmers/breeders for a longtime [3].

The influence of the social groups that are formed is different, there are only influential for its members, there are influential for the surrounding community, and there is also an effect on the survival of the people or society, so as to be able to realize the development program. Within the social group itself, there is a social capital created by the frequent interaction patterns among members within the social group. Social capital is an intangible capital and is usually rarely noticed. However, one of the factors influencing the development of a social group is the social capital that exists within the group itself. Social capital places greater emphasis on the potential of groups and patterns of relationships between individuals within a group and between groups with an attention space on social networks, norms, values, and beliefs to fellow-born members of the group and the norm of the group. The essence of social capital is how the ability of people in a group to work together to build a network to achieve common goals. The partnership is a system of alliances that include various agribusiness activities ranging from pre-production and production to marketing [4]. Social capital refers to the values and norms that are believed and carried out by most members of society in 
Citation: Tanri Giling Rasyid., ST. Rohani, Muhammad Aminawar, Muhammad Darwis, 2018. The Level of Social Capital And Its Effect on The Participation of Farmers on Goat Livestock Business Development In Jeneponto Regency South Sulawesi Province-Indonesia. Advances in Environmental Biology., 12(2): 1-3.

everyday life, which directly or indirectly affect the quality of life of individuals and the sustainability of the community. This research aimed to describe the level of social capital and participation rate of goat farmers in Jeneponto Regency.

Research Methods:

This research was conducted in District Tamalatea, Bontoramba, and Kelara Jeneponto Regency South Sulawesi Province. With the consideration that the district is a center of goat production. This study was conducted from July to September 2017. The population of the study was 11,202 goat breeders or included in 1,061 groups spread over Jeneponto Regency. Given the size of goat breeder population is large, the technique of determining the sample using multi stage cluster sampling technique [5], namely Jeneponto Regency selected 3 districts that have the largest number of goats, Tamalate District (32,516 tail), Bontoramba District $(19,336$ tail), and Kelara District (15,873 tail) [6]. From each district, 25 farmers were chosen as the respondent or the sample farmer so that the total was 75 goat farmers. The sampling technique was done randomly simple. Data was analyzed using Likert scale. To measure the indicator of social capital and farmer participation used scores ranging from 1 to 3 with a rating of $1=$ low; $2=$ medium; and $3=$ height

\section{RESULTS AND DISCUSSION}

Level of Social Capital of Goat Farmers:

The results showed that the average level of social capital of goat farmers in Jeneponto Regency was in the high category of 29.0\%, medium category of $62.9 .0 \%$, and low category by $8.2 \%$. This condition indicates that goat farmers in Jeneponto Regency still have sufficient social capital in the development of their goat farming business. For more details, please refer to Table 1 below.

Table 1: Level of Social Capital of Goat Farmers in Jeneponto Regency

\begin{tabular}{|l|l|l|l|}
\hline \multirow{2}{*}{ Number } & \multirow{2}{*}{ Social Capital } & \multicolumn{3}{|l|}{ Level of Social Capital of Farmers $(\%)$} \\
\cline { 3 - 4 } & & High & Medium \\
\hline 1. & Trust & 34,3 & 53,3 \\
\hline 2. & Network & 30,3 & 65,5 \\
\hline 3. & Social norm & 22,3 & 69,8 \\
\hline Total (\%) & & 86,9 & 12,4 \\
\hline Average(\%) & 29,0 & 4,2 \\
\hline
\end{tabular}

Source: Primary Data After Processed, 2017.

The level of social capital owned by goat farmers in Jeneponto Regency is in the medium category. This is because of the respondents who gave the assessment and felt that the social capital among goat farmers slowly decreased. Whereas social capital is needed in a group in order to strengthen the activities of farmers groups in goat farming business. According to [7], high social capital will increase cooperation network, social relationship, and interaction between farmers and groups in seeking innovation information, cooperation in farming activities, and innovation implementation in an effort to increase production and population of goats. Thus, it is expected to strengthen the participation of farmers in developing goat breeding business to be more productive and provide great benefits for increasing income and welfare of farmers.

Added by [8] stating that by relying on shared norms and values, human relations will result in mutual trust which in turn has a large and measurable economic value. [9] argues that social capital is an important factor to be considered in agricultural development and rural economic development.

[10] argues that social groups usually form traditionally on the basis of linkage, repeated social experiences and the similarity of belief in the dimensions of the divinity (separated social experiences) and the similarity of belief in the divine dimension ( religious beliefs) tend to have level cohesiveness, but the range of networks and trusts are narrowly awakened. In contrast to groups built on the basis of shared orientation and objectives and with more modern organizational management features will have better member participation rates and a broader network range and will have a positive impact on group progress and contribute to broad community development.

Goat Farmers Participation Rate:

The results showed that the average participation rate of goat breeders in Jeneponto Regency was in the high category (64.9\%), medium (28.6\%) and low $(6.5 \%)$. This condition illustrates that farmers are quite active in developing their goat farming business. Goat breeder's participation rate can be seen in Table 2.

Table 2: Participation Rate of Goat Farmers in Jeneponto Regency

\begin{tabular}{|l|l|l|l|l|}
\hline \multirow{2}{*}{ Number } & \multirow{5}{*}{ Stages of Participation } & Farmer Participation Rate (\%) & Medium & Low \\
\cline { 3 - 5 } & & High & 32,3 & 12,4 \\
\hline 1. & Planning & 55,3 & 28,3 & 4,2 \\
\hline 2. & Implementation & 67,5 & 21,3 & 5,9 \\
\hline 3. & Utilization & 72,8 & 32,4 & 3,5 \\
\hline 4. & Evaluation & 64,1 & 28,6 & 6,5 \\
\hline Average & & 64,9 & \\
\hline
\end{tabular}

Source: Primary Data Processed, 2017.

Table 2. shows that there is a difference in farmer participation rate where the planning and evaluation elements are relatively higher compared to the implementation and utilization elements. The participation rate of goat farmers is high category. This is due to the fact that the majority of farmers are farmers who have kept goats with breeding experience for more than 5 years and have also joined the farmer group of livestock for more than 2 years. So, the breeders have tasted and enjoyed the results of the goat breeding activity. According to [11], participation by all farmers is conscious and voluntary. The form of participation is not just material (money, things, things), but can be in the form of ideas (ideas, information, suggestions, energy, thought, etc.). Participation is also a form of accountability to livestock farmer groups. Participation also requires a contribution to the interests and objectives of farmer-livestock groups.

[12] States that the level of participation is determined by the high level of capital owned by a person. Participation can only be done if someone has social capital that is network, clear rules or norms, and trust. [13] argues that to build participation requires four major stages of initiation, building trust, expected levels of participation and stages, and sustainability. The sustainability of such participation is largely determined by the number of programs that farmers follow and the benefits derived from the program are in accordance with what the farmers want.

\section{The Influence of Social Capital on Goat Farmers Participation Rate:}

The result showed that social capital variable had positive effect to farmer participation variable. This is evidenced by the results of calculations using simple linear regression analysis, it is known that social capital variables significantly influence the participation of farmers shown by $F_{\text {count }}$ of $176,110>F_{\text {table }}$ of 4.00 or significant value $\mathrm{F}$ of $0.000<$ real level of 0.05 . With the contribution of $86 \%$ indicated by the coefficient of determination (R2) of 0.860 means this result indicates that the variation (ups and down) participation of farmers by $86 \%$ caused by the influence of social capital while the remaining $14 \%$ caused by other factors. The results of [14] research indicate that the element of social capital has a significant effect on the participation of goat farmers in Jeneponto Regency, so [13] states that social network is a form of social capital depicted in the form of feeling, , and obligations and bound by norms or rules. Further stated that this network can be formed because it comes from the same area, the similarity of trust. This social network is organized into an institution that gives special treatment to those formed by the network. 
Citation: Tanri Giling Rasyid., ST. Rohani, Muhammad Aminawar, Muhammad Darwis, 2018. The Level of Social Capital And Its Effect on The Participation of Farmers on Goat Livestock Business Development In Jeneponto Regency South Sulawesi Province-Indonesia. Advances in Environmental Biology., $12(2)$ : 1-3.

The result of analysis by using simple linear regression of social capital influence to farmer participation can be seen in Table 3 .

Table 3: Simple Linear Regression Analysis Result Influence of Social Capital (X) to Farmer's Participation (Y).

\begin{tabular}{|l|l|l|l|l|l|l|}
\hline Variable Independet & Variable Dependent & $\begin{array}{l}\text { Koefisien Regresi } \\
(\mathrm{B})\end{array}$ & $\begin{array}{l}\text { Koefisien Korelasi } \\
(\mathrm{r})\end{array}$ & T Count & Sig. \\
\hline Konstanta & $\mathrm{Y}$ & 4,404 & & 6,105 & 0,000 \\
$\mathrm{X}$ & & 0,753 & 0,860 & 13,271 & 0,000 \\
\hline
\end{tabular}

Source: Primary Data after Processed, 2017

Description: Significant at $\alpha=0.05$.

Table 3 shows that the regression coefficient of independent variables and standard error, then can be formed simple linear regression equation as follows:

$\mathrm{Y}=4,404+0,753 \mathrm{X}$

From the simple linear regression equation, obtained value a which is a constant of 4.404 . This shows that if the value of the independent variable is 0 or none then the farmer's participation will be worth 4,404 . The coefficient of regression of social capital variable (X) is 0,753 , it means that social capital give oneway effect, meaning that if social capital increases then farmer participation will also experience increase equal to 0,753 . To know the closeness of relationship between social capital variable with farmer participation.

The value of correlation coefficient ( $\mathrm{r}$ ) obtained by 0.860 , means that there is a positive relationship between the two variables. This is also evidenced by the significance $(0.000)<(0,05)$ which can be concluded that social capital variable $(\mathrm{X})$ has significant (real) influence to farmer's participation $(\mathrm{Y})$. This means that the participation of farmers depends on social capital.

According to [15], states that social network is a form of social capital depicted in the form of feelings, sympathy, and obligations and bound by norms or rules. Further stated that this network can be formed because it comes from the same area, the similarity of trust. This social network is organized into an institution that gives special treatment to those formed by the network.

[16] Divides social capital into two parts: social capital which tends to be exclusive both group managers and group members in the context of ideas, relationships, and attention, more inward looking or oriented. The various societies or individuals belonging to the group are generally homogeneous, and the focus is on keeping the value of heredity recognized and executed as part of the code of conducts and the moral code (code of ethics) of the tribe or social entity the. They tend to be conservative and tend to prioritize solidarity making rather than more real things to build themselves and groups in accordance with the demands of values and norms of a more open society. From the results and this discussion, it can be said that there is a positive relationship between social capitals with the participation of farmers.

Conclusions:

Based on the result and discussion, it can be concluded that (1) the level of social capital in the goat breeder group in Jeneponto Regency is still low from all aspects of social capital ie manual trust, reciprocity, and networking; (2) goat breeder participation rate in Jeneponto Regency is in high category; and (3) social capital significantly affect the participation of goat farmers in Jeneponto Regency.

\section{REFERENCES}

[1] Sirajuddin, S.N.A., S. Asnawi, Syawal, M. Jamal, 2016. Response of Cattle Breeders to Rice Straw Silage in Soppeng Regency, South Sulawesi Province. American Eurasian Journal of Sustainable Agriculture, 10(3): 33-36.

[2] Rasyid, T.G., S. Hasan, S. Rasjid, S.N. Sirajuddin, 2016. Development Model of Goat Farming Business Base On Productive Economy in Majene Regency, West Sulawesi, Indonesia. American-Eurasian Journal of Sustainable Agriculture, 10(3): 1-5.

[3] Sirajuddin, S.N., S. Nurlaelah, A.A. Amrawaty, Amrullah, S.T. Rohani, I.M. Saleh, 2016. Relationship between Farmers Characteristicand Income from Beef Cattle with TheTraditional Profit-Sharing. American-Eurasian Journal Of Sustainable Agriculture, 11(5): 29-34.

[4] Sirajuddin, S.N., A.R. Siregar, P. Mappigau, 2017. Adoption Rate of Beef Breeders Technology Following Partnership System In Barru Regency. AmericanEurasian Journal of Sustainable Agriculture, 11(6): 31-34.

[5] Sugiyono. 2013. Combined Research Methods (Mixed Methods). Alfabeta, Bandung.

[6] Central Bureau of Statistics Jeneponto Regency. 2016. Jeneponto Regency In Figures 2016. Office of Central Bureau of Statistics Jeneponto, Jeneponto.

[7] Hadi, S., 2014. Profile of Social Capital and Farmer Participation Rate on Beef Cattle Development in Tebo District Jambi Province. KANAL 2(2): 107206.

[8] Fukuyama, F., 2002. Social Capital and Development. The Coming Agenda. SAIS Review XXII. Free Press, New York.

[9] Bolu, Y.G., 2011. Study of the Influence of Social Capital and Information Supply of Innovation on Level of Innovation of Corn Maize in East Lombok Regency. Dissertation. Graduate School of Gadjah Mada University, Yogyakarta.

[10] Rasyid, T.G., 2016. Alternative Model of Goat-Based Livestock Development Based on Socio-Economic in Majene District, West Sulawesi Province. Postgraduate Program of Hasanuddin University. Dissertation. Makassar.

[11] Saragih, T.P., 2004. Realizing the Autonomy of Villagers, Alternative of Village Empowerment. CV. Cipruy, Jakarta.

[12] Haeruman, J.H., 2005. The Paradigm of the Future of Natural Resources Management of Indonesia. Proceeding. National Seminar of Faculty of Forestry Bogor Agricultural University, Bogor.

[13] Rasyid, T.G., ST. Rohani, Muhammad Aminawar, 2017. Strengthening of Social Capital Institution and Its Impact on Development of Goat-Based Livestock Economy Based Business in Jeneponto Regency of South Sulawesi Province. First Year Report on Superior Research of Higher Education. Institute for Research and Community Service Hasanuddin University, Makassar.

[14] Pratikno, 2008. Knitting Social Capital for Peace and Social Integration. Fisipol UGM, Yogyakarta.

[15] Hasbullah, J., 2006. Social Capital, Towards Human Excellence Indonesia, MR United Press, Jakarta.

[16] Saragih, T.P., 2004. Realizing the Autonomy of Villagers, Alternative of Village Empowerment. CV. Cipruy, Jakarta. 